\title{
Development of heat treatments for two species of Samoan fruit flies (Bactrocera spp., Diptera: Tephritidae)
}

\author{
Fa'alelei Tunupopo ${ }^{1}$, Fai'ilagi Sa’ili ${ }^{1}$, Lisa E. Jamieson², Samuel D. J. Brown" ${ }^{2 *}$ \\ ${ }^{1}$ Nu'u Crops Division, Ministry of Agriculture, PO Box 1874, Apia, Samoa \\ ${ }^{2}$ The New Zealand Institute for Plant and Food Research Limited, PO Box 92169 Mt Albert, \\ Auckland, New Zealand \\ *Corresponding author: samuel.brown@plantandfood.co.nz
}

\begin{abstract}
Of the seven species of Bactrocera fruit flies found in Samoa, only two (B. kirki (Froggatt) and B. xanthodes (Broun)) are of economic importance. These species attack a range of fruit, including papaya (Carica papaya), breadfruit (Artocarpus altilis), eggplants (Solanum melongena) and guava (Psidium guajava). The presence of these two species limits export market access for Samoan produce. Eggplants and breadfruit infested with the eggs of $B$. kirki and B. xanthodes, respectively, were treated using a high-temperature forced-air (HTFA) protocol to heat the fruits to core temperatures of $40^{\circ} \mathrm{C}, 42^{\circ} \mathrm{C}, 44^{\circ} \mathrm{C}$ or $46^{\circ} \mathrm{C}$. No B. xanthodes pupae emerged from fruit treated at $42^{\circ} \mathrm{C}$ or greater. Pupae of $B$. kirki were found from fruit treated at temperatures up to $44^{\circ} \mathrm{C}$, but failed to survive treatments at $46^{\circ} \mathrm{C}$. The HTFA protocol previously approved for treatment of other Pacific fruit flies (fruit core temperature to $47.2^{\circ} \mathrm{C}$ for $20 \mathrm{~min}$ ) works without modification for treatment of the two combinations of fruit flies and commodities tested. However, less intense HTFA treatments are worth investigating, if required to enhance fruit quality.
\end{abstract}

Keywords South Pacific, horticulture, agriculture, disinfestation, quarantine treatment.

\section{INTRODUCTION}

Increasing horticultural exports from Pacific Island nations is a key aspect to growing their economies. However, the presence of various tephritid fruit fly species is a critical barrier to gaining access for Pacific produce to the major markets of New Zealand and Australia.

The high-temperature forced-air (HTFA) method of disinfesting fruit was developed by the US Department of Agriculture in Hawaii to eliminate fruit fly larvae from papaya to allow the export of fruit from Hawaii to the US mainland (Armstrong et al. 1989). HTFA works by moving hot air over the fruit until the fruit core temperatures reach a set target temperature. This provides quarantine security by heating the fruit above the thermal limits of fruit fly eggs and larvae, inducing mortality.

The currently approved HTFA quarantine treatments for exported fruits from the South Pacific were developed between 1991 and 1999 during the Regional Fruit Fly Project (RFFP) that involved Fiji, Tonga, Western Samoa, Cook Islands, Vanuatu, Solomon Islands, and the Federated States of Micronesia (Ferrer 1997; McGregor 1997). This programme identified B. melanotus (Coquillett, 1910) from the Cook Islands as the most heat-tolerant species within the participating nations and developed a HTFA protocol (maintenance of a fruit core temperature of $47.2^{\circ} \mathrm{C}$ for $20 \mathrm{~min}$ ) for disinfestation of papaya (Waddell et al. 1997a; Waddell et al. 1997b; IPPC 2016). This protocol was widely accepted, and many countries (Tonga, Samoa, Fiji, Cook 
Islands) implemented this protocol for exports of fresh produce using HTFA units installed as part of the RFFP.

Seven species of fruit fly (Diptera: Tephritidae) occur in Samoa and two of these (Bactrocera kirki (Froggatt, 1910) and B. xanthodes (Broun, 1904)) are of particular biosecurity concern as their presence limits market access of Samoan produce. Bactrocera kirki is indigenous to the central Pacific archipelagos of Samoa, Tonga, Niue, and Wallis and Futuna. It was accidentally introduced to the Austral Islands (French Polynesia) in the 1970s (Purea et al. 1997) and it is considered to be one of the most serious fruit fly pests in the Pacific (Drew \& Romig 1997). Bactrocera xanthodes is likewise indigenous to the central Pacific, but has a broader geographic range that additionally includes the Cook Islands, French Polynesia, Fiji and Vanuatu. The larvae of B. xanthodes have been intercepted during biosecurity assessments of produce, especially breadfruit, imported into New Zealand (Li et al. 2019).

The other five species of fruit fly known in Samoa are: B. distincta (Malloch, 1931); B. obscura (Malloch, 1931); B. samoae Drew, 1989; B. aenigmatica (Malloch, 1931); and an undescribed species closely related to $B$. paraxanthodes (Drew \& Hancock 1995; Drew et al. 1997; Drew \& Romig 1997; Heimoana et al. 1997). These species are found infrequently in the inedible fruits of rainforest plants that are not exported e.g. fruits of an unidentified Ficus sp. (Moraceae) and Aglaia samoensis A. Gray (Meliceae).

Work on B. kirki and B. xanthodes in Samoa during the 1990s involved investigations into the efficacy of heat-treatment to kill the insects (Fonoti \& Tunupopo 1997a, b). Additional relevant research on $B$. xanthodes wasconducted around the same time in Fiji (Tora Vueti et al. 1997), Tonga (Foliaki \& Armstrong 1997) and the Cook Islands (Waddell et al. 1997b). Much of that previous research explored the possibility for increasing exports of papaya (Carica papaya L.) from Samoa but breadfruit (Artocarpus altilis (Parkinson) Fosberg) became of greater interest during the early 2000s and also since then.
Therefore, the aim of this study was to determine the effect of heat-treatment of $B$. xanthodes on breadfruit and $B$. kirki on eggplant, another potential export crop which is favoured by $B$. kirki. Eggs are the life stage most resistant to heat treatment, so this study focused on mortality of eggs and was conducted in 2003 using a pilotscale HTFA treatment chamber, which was operational at that time. Recent work on the postharvest quality of breadfruit (Artocarpus altilis) after disinfestation with hot-air or hotwater treatments (Molimau-Samasoni et al. 2019) has highlighted the need to publish the results of this earlier study.

\section{MATERIALS AND METHODS Fruit fly colonies}

Four cages of each of B. xanthodes and B. kirki were established at Nu'u Research Station, 'Upolu, Samoa, from field-collected breadfruit (Artocarpus altilis var. 'Puou') and talie (Terminalia catappa L.) fruits, respectively.

Fruit fly eggs were collected using the papaya fruit dome method (Walker et al. 1997) consisting of a halved and hollowed papaya with the skin punctured using a 1-mm diameter needle. Two fruit domes were placed in each cage for oviposition periods of $2 \mathrm{~h}$ for $B$. kirki or $4 \mathrm{~h}$ for $B$. xanthodes. Eggs were collected by using water in a hand sprayer to wash out the domes onto clean Petri dishes (Walker et al. 1997).

\section{Fruit infestation}

A preferred host fruit was used for each of the two fly species, in order to encourage fruit fly development. This was also to ensure high survival of larvae that hatched from eggs that survived the treatment through to adult emergence to effectively assess efficacy at different temperatures. Mature breadfruit (var. 'Puou') were harvested from Saleimoa, 'Upolu, Samoa, on 8 December 2003. Mature eggplants (Solanum melongena L., unnamed local variety) were bought from the local market at Fugalei, 'Upolu, Samoa, on 10 December 2003. Fruits were washed and artificially inoculated with fruit fly eggs in the laboratory at Nu'u Research Station. 
Prior to infestation, fruit were weighed and labelled. A flap 5-mm deep was cut into the shoulder of each fruit and an incision made into the flesh of the fruit. Eggs were placed into the incision using a plastic Pasteur pipette. Breadfruits were infested with 200-250 eggs of $B$. xanthodes and eggplants were infested with about 200 eggs of B. kirki. After infestation, flaps were replaced and sealed with masking tape. Fruit were infested 4-5 hours before treatment. Twenty fruit were allocated to each of five different treatments, being an untreated control, which was retained at ambient temperature $(\approx$ $27^{\circ} \mathrm{C}$ ), and four HTFA treatments with different fruit core target temperature endpoints $\left(40^{\circ} \mathrm{C}\right.$, $\left.42^{\circ} \mathrm{C}, 44^{\circ} \mathrm{C}, 46^{\circ} \mathrm{C}\right)$.

\section{HTFA treatment}

Treatments were conducted during December 2003 using a semi-commercial/research hightemperature forced-air (HTFA) treatment chamber and the Experimental Mode of the QTITreat version 4 software (Quarantine Treatments International, Queenstown, New Zealand) located at Atele Horticultural Centre, 'Upolu, Samoa.

Fruit were delivered into the HTFA chamber in plastic lugs (crates) with ventilated bases. The 14 temperature probes were inserted into the centre of randomly selected fruit within each treatment as they were put into the HTFA chamber, and probed fruit were randomly arranged in the lugs. Treatments began with fruit core temperatures at ambient temperature $\left(\approx 27^{\circ} \mathrm{C}\right)$. Relative humidity during treatments ranged between $69 \%$ and $92 \%$, with a mean of $80 \%$. Separate HTFA runs were used to treat each fruit core target temperature and each fruit species. Eggplants were treated using a 'Sine Curve' profile (Fig. 1, dark line), while breadfruit were treated using an 'Exponential' heating profile (Fig. 1, pale line). Treatments took between 2 and $3 \mathrm{~h}$ to reach the target fruit core temperatures in eggplants, and between 3 and $5 \mathrm{~h}$ to reach the target fruit core temperatures in breadfruit (Table 1). Treatments were completed when the last of the 14 probes reached the target fruit core temperature and

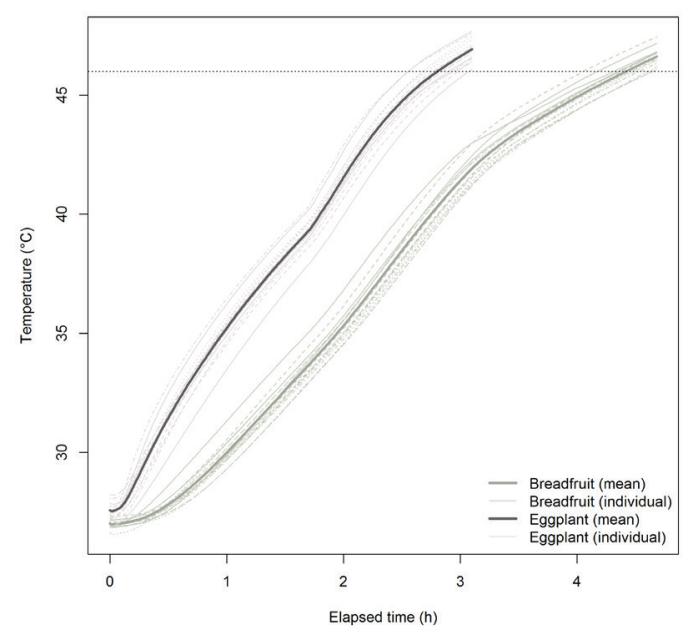

Figure 1 Temperature profile of high-temperature forced-air (HTFA) runs with a fruit core target temperature of $46^{\circ} \mathrm{C}$. Grey lines represent individual fruit probes. The heavy line shows the mean temperature for each fruit. Dark grey = eggplant, light grey = breadfruit. The dotted horizontal line shows the target temperature of $46^{\circ} \mathrm{C}$.

fruits were removed immediately. There was no holding period for any of the treatments and fruit were not hydro-cooled after treatment.

Heat-treated fruits were air-cooled at ambient temperatures in a fruit fly-proof room to prevent reinfestation. After cooling, fruit were placed individually in containers lined with a layer of sawdust ( $5 \mathrm{~mm}$ deep) in the bottom as a pupation medium and with mesh lids. Breadfruit were held in 10-L plastic buckets, while eggplants were held in 2-L plastic boxes. Samples were held at ambient temperature $\left(\approx 27^{\circ} \mathrm{C}\right)$.

\section{Assessments}

Control and treated fruit were assessed after 10 days (eggplants) or 12 days (breadfruit) by removal of the pupae from sawdust by sieving. Any pupae collected were counted before being placed into smaller containers lined with sawdust to await adult eclosion, and were assessed 8 days later. 
Table 1 Pupal and adult emergence after high-temperature forced-air (HTFA) treatment of Bactrocera kirki eggs in eggplant and Bactrocera xanthodes eggs in breadfruit.

\begin{tabular}{cccccccc}
\hline $\begin{array}{c}\text { Commodity/ } \\
\text { fruit fly } \\
\text { species }\end{array}$ & $\begin{array}{c}\text { Target } \\
\text { fruit core } \\
\text { temperature } \\
\left({ }^{\circ} \mathrm{C}\right)\end{array}$ & $\begin{array}{c}\text { Treatment } \\
\text { duration } \\
(\mathrm{h} \text { :min) }\end{array}$ & $\begin{array}{c}\text { Mean } \\
\text { fruit mass } \\
(\mathrm{g})\end{array}$ & $\begin{array}{c}\text { Expected } \\
\text { minimum } \\
\text { number of } \\
\text { pupae }\end{array}$ & $\begin{array}{c}\text { Mean } \\
\text { number } \\
\text { of pupae }\end{array}$ & $\begin{array}{c}\text { Mean } \\
\text { percentage } \\
\text { mortality }\end{array}$ & $\begin{array}{c}\text { Percent } \\
\text { of pupae } \\
\text { eclosing to } \\
\text { adults }\end{array}$ \\
\hline $\begin{array}{c}\text { Eggplant/ } \\
\text { B. kirki }\end{array}$ & 27 & - & 242 & 143 & 145.6 & 11 & 75 \\
& 40 & $2: 02$ & 233 & 143 & 50.7 & 56 & 80 \\
& 42 & $2: 18$ & 214 & 143 & 33.1 & 67 & 59 \\
& 44 & $2: 34$ & 218 & 143 & 20.0 & 78 & 51 \\
\hline Breadfruit/ & 46 & $3: 07$ & 196 & 143 & 0 & 100 & - \\
B. xanthodes & 27 & - & 940 & 120 & 165.2 & 5 & 87 \\
& 40 & $2: 55$ & 1084 & 120 & 70.2 & 44 & 81 \\
& 42 & $3: 18$ & 1143 & 120 & 0 & 100 & - \\
& 44 & $3: 54$ & 960 & 120 & 0 & 100 & - \\
\hline
\end{tabular}

\section{Statistical analyses}

The expected minimum number of survivors was calculated from the lower bound of the 95\% confidence interval of the mean number of pupae emerging from control fruits. One-way analyses of variance (ANOVA) were conducted in R 3.4.1 (R Core Team 2015) and unplanned multiple comparisons were carried out using the Tukey post hoc significance test (Zar 1999).

\section{RESULTS}

As expected, the time to reach the target temperatures were longer in breadfruit (mean weight $1.02 \mathrm{~kg}$ ) compared with eggplants, which were smaller (mean weight $0.22 \mathrm{~kg}$ ) (Table 1). This resulted in the heating rates applied to the eggs of $B$. xanthodes in breadfruit being lower $\left(0.073^{\circ} \mathrm{C} / \mathrm{min}\right)$ than the heating rates applied to the eggs of $B$. kirki in eggplants $\left(0.106^{\circ} \mathrm{C} / \mathrm{min}\right)$ (Fig. 1). Therefore, direct comparisons between B. xanthodes and B. kirki survival rates from the HTFA treatments cannot be made because they were treated in different host fruits that would have different rates of thermal diffusivity and, therefore, exhibit different heating profiles during HTFA treatment.

Fruit fly survival decreased with increasing treatment temperatures (Figs. 2 \& 3). Emergence of $B$. xanthodes pupae occurred in breadfruit treated to a core temperature of $40^{\circ} \mathrm{C}$ but not when fruits had been treated to core temperatures of $42^{\circ} \mathrm{C}$ or higher (Fig. 2). Differences between survival rates at $27^{\circ} \mathrm{C}, 40^{\circ} \mathrm{C}$, and $42^{\circ} \mathrm{C}$ and greater were highly significant (ANOVA, $\mathrm{F}_{4,95}=130.4$, $\mathrm{P}<0.0001$, Tukey post hoc test). Emergence of $B$. kirki occurred in eggplants treated up to $44^{\circ} \mathrm{C}$ and below, but not when the fruits had been heated up to $46^{\circ} \mathrm{C}$ (Fig. 3). There were no significant differences between the survival of $B$. kirki across the fruit core temperatures of $40^{\circ} \mathrm{C}$ and $44^{\circ} \mathrm{C}$, or between $44^{\circ} \mathrm{C}$ and $46^{\circ} \mathrm{C}$. In both fruit fly species, survival to pupal stage in fruit retained at ambient temperature $\left(\approx 27^{\circ} \mathrm{C}\right)$ was significantly greater than survival after HTFA treatments (ANOVA, $\mathrm{F}_{4,95}=47.41, \mathrm{P}<0.0001$, Tukey post hoc test).

The percentage of pupae eclosing to adults in the controls and after HTFA treatment to a core temperature of $40^{\circ} \mathrm{C}$, was between $75 \%$ and $87 \%$ for both fruit fly species (Table 1). However, $B$. kirki pupae from eggplants treated to a core 


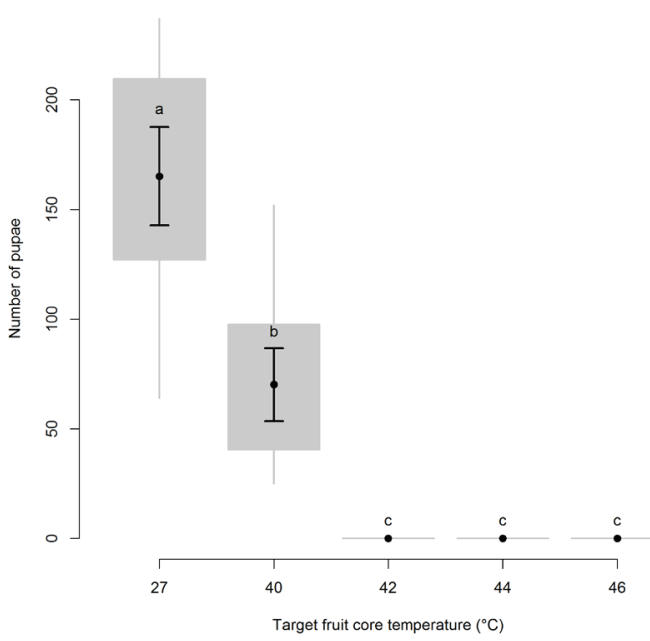

Figure 2 Decreasing pupation of Bactrocera xanthodes after high-temperature forced-air (HTFA) treatments of breadfruit infested with $B$. xanthodes eggs. Box and whisker plots show the range and quartiles of the data. Central point and error bars show the mean and 95\% confidence interval. Different letters indicate significantly different treatments.

temperature of $42^{\circ} \mathrm{C}$ or $44^{\circ} \mathrm{C}$ were significantly less likely to eclose to adults than those from eggplants exposed to lower temperatures (ANOVA, $\mathrm{F}_{3,58}=10.09, \mathrm{P}=0.032$, Tukey post hoc test) (Fig. 4).

\section{DISCUSSION}

No $B$. xanthodes pupae were found from breadfruit heated to $\geq 42^{\circ} \mathrm{C}$ with no holding period and no B. kirki pupae developed from eggplants heated to $46^{\circ} \mathrm{C}$ with no holding period. Therefore, the heat treatment protocol previously approved for treatment of other Pacific fruit flies (i.e. fruit core temperature to $47.2^{\circ} \mathrm{C}$ for 20 $\mathrm{min}$ ) is acceptable for use without modification for treatment of either of these species of fruit fly on the fruit species tested. However, as these treatment conditions have been found to negatively impact breadfruit quality (MolimauSamasoni et al. 2019), our results suggest that less intense HTFA treatments could be developed which do not compromise quarantine efficacy.

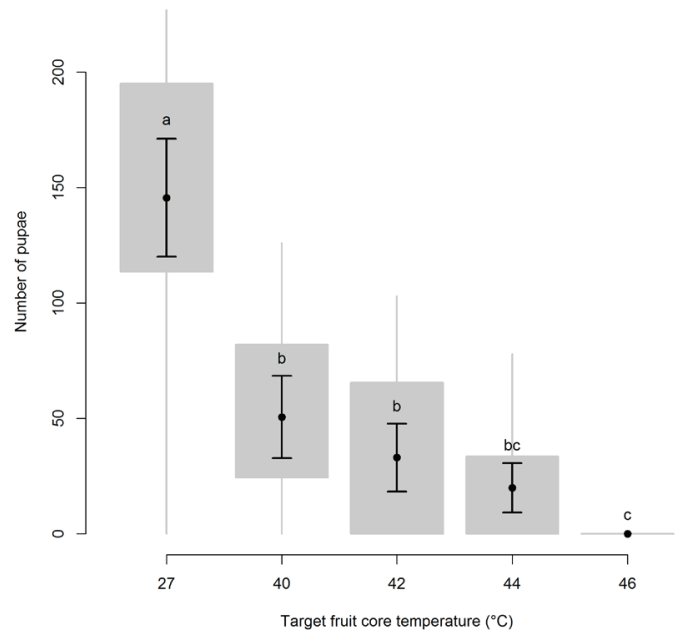

Figure 3 Decreasing pupation of Bactrocera kirki after high-temperature forced-air (HTFA) treatment of eggplants infested with B. kirki eggs. Box and whisker plots show the range and quartiles of the data. Central point and error bars show the mean and 95\% confidence interval. Different letters indicate significantly different treatments.

However, further experiments will need to be undertaken to treat the numbers of insects required to gain regulatory approval.

Fonoti and Tunupopo (1997a, 1997b) demonstrated a greater heat tolerance for B. kirki eggs than for B. xanthodes eggs. Although our results are, at face value, consistent with their findings, the differing experimental conditions used in the current study confounds comparisons between B. kirki and B. xanthodes.

Empirical studies of fruit fly thermal tolerances have shown substantial variation both within and between species (Heard et al. 1992; Foliaki \& Armstrong 1997; Sales et al. 1997; Tora Vueti et al. 1997; Waddell et al. 1997a; Armstrong et al. 2009; Hallman et al. 2011). Higher-than-optimal temperatures negatively affect a wide range of insect physiological systems, including metabolic pathways, respiration and cell membranes (Neven 2000). However, these mechanisms are too poorly understood to predict mortality during HTFA treatments. In particular, it 


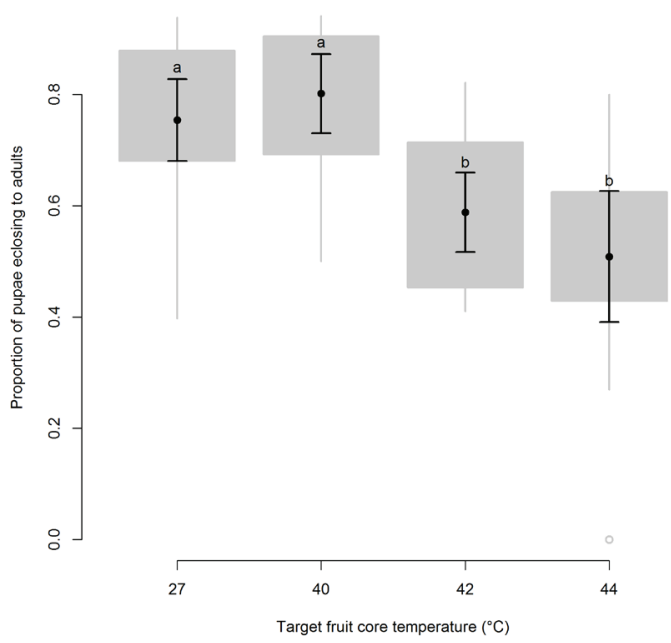

Figure 4 Proportion of Bactrocera kirki pupae that eclose to adults following high-temperature forced-air (HTFA) treatment of eggplants infested with $B$. kirki eggs. Box and whisker plots show the range and quartiles of the data. Central point and error bars show the mean and 95\% confidence interval. Different letters indicate significantly different treatments.

remains unclear whether temperature and time have thresholds above which heat injuries occur rapidly; or if heat injuries accumulate across a broader range of temperatures.

The lower percentage of $B$. kirki pupae which eclosed to adults after treatment to fruit core temperatures of $42^{\circ} \mathrm{C}$ and $44^{\circ} \mathrm{C}$ suggests that the physiological pathways affected by heating to these temperatures during egg development are critical for adult eclosion but allow larval development. Although delayed mortality after heat treatments have been previously reported in fruit flies (Xie et al. 2008), the significance of this latency has not been explored.

Phylogenetic relationships may also be important in understanding the heat tolerance of tephritid fruit flies. Bactrocera xanthodes is placed in a separate subgenus (Notodacus) from B. kirki, which, along with B. melanotus, is in the nominate subgenus Bactrocera. Phylogenies of the genus have been published (Virgilio et al. 2015; San Jose et al. 2018), and should be considered in future comparative research on fruit fly heat tolerance.

Unfortunately, for various reasons, most of the HTFA units established in the South Pacific during the RFFP are no longer in operation. HTFA facilities in Fiji and New Caledonia, are the only units in the Pacific Islands that remain certified and in current use. With renewed interest in exporting fresh produce from the Pacific, it will be important that lessons be learned from the successful Fijian and New Caledonian models of operating commercial HTFA units, to overcome the obstacles that led to previous closures. The historic data summarised in this paper are also of importance to inform future research into the optimal treatment profiles to support this renaissance of HTFA fruit treatments in the South Pacific.

\section{CONCLUSIONS}

The heat-treatment protocol previously approved for treatment of other Pacific fruit flies (i.e. heating the fruit core to a temperature of $47.2^{\circ} \mathrm{C}$ with a holding period of $20 \mathrm{~min}$ at that temperature) is acceptable for use without modification for treatment of the two combinations of fruit flies and commodities tested. Indeed, these results suggest that this treatment exceeds the heat tolerance of $B$. xanthodes and B. kirki, leading to the possibility of developing less intense treatments, if required to enhance fruit quality.

\section{ACKNOWLEDGEMENTS}

We wish to thank Emma Tora Vueti (Secretariat for the Pacific Community), Laisene Samuelu (Ministry of Agriculture) and the staff of Atele Horticultural Centre and the Crops Division Fruit Fly Team for their assistance and comments on our research. Richard Cook, Saleimoa, supplied breadfruit. Natalie Page-Weir, Jessica Dohmen-Vereijssen, Janine Johnson (Plant and Food Research) and Jack Armstrong (Quarantine Scientific Ltd.) provided comments on the manuscript. This research was funded by the Ministry of Agriculture, Samoa. 


\section{REFERENCES}

Armstrong J, Hansen J, Hu B, Brown S 1989. High temperature, forced-air quarantine treatment for papayas infested with tephritid fruit flies (Diptera: Tephritidae). Journal of Economic Entomology 82: 1667-1674.

Armstrong JW, Tang J, Wang S 2009. Thermal death kinetics of Mediterranean, Malaysian, melon, and oriental fruit fly (Diptera: Tephritidae) eggs and third instars. Journal of Economic Entomology 102: 522-532.

Drew RAI, Hancock DL 1995. New species, subgenus and records of Bactrocera Macquart from the South Pacific (Diptera: Tephritidae: Dacinae). Journal of the Australian Entomological Society 34: 7-11.

Drew RAI, Romig MC 1997. OverviewTephritidae in the Pacific and Southeast Asia. In: Allwood AJ, Drew RAI eds. Management of Fruit Flies in the Pacific. A regional symposium, Nadi, Fiji 28-31 October 1996. Australian Centre for International Agricultural Research, Canberra. Pp. 46-53.

Drew RAI, Allwood AJ, Tau D 1997. Bactrocera paraxanthodes Drew and Hancock-an example of how host records and attractant responses contribute to taxonomic research. In: Allwood AJ, Drew RAI eds. Management of Fruit Flies in the Pacific. A regional symposium, Nadi, Fiji, 28-31 October 1996. Australian Centre for International Agricultural Research, Canberra. Pp. 131133.

Ferrer P 1997. Fruit fly research and development in the South Pacific. In: Allwood AJ, Drew RAI eds. Management of Fruit Flies in the Pacific. A regional symposium, Nadi, Fiji 28-31 October 1996. Australian Centre for International Agricultural Research, Canberra. Pp. 43-45.

Foliaki S, Armstrong JW 1997. Heat tolerances of immature stages of Bactrocera facialis and $B$. xanthodes (Diptera: Tephritidae). In: Allwood AJ, Drew RAI eds. Management of Fruit Flies in the Pacific. A regional symposium, Nadi, Fiji, 28-31 October 1996. Australian Centre for International Agricultural Research,
Canberra. Pp. 239-246.

Fonoti P, Tunupopo F 1997a. Response of Western Samoan Bacterocera xanthodes to hot water immersion treatments. New Zealand Ministry of Agriculture - Regulatory Authority.

Fonoti P, Tunupopo F 1997b. Response of Western Samoan Bactrocera kirki to hot water immersion treatments. The Samoan Ministry of Agriculture, Forests, Fisheries and Meteorology (MAFFM).

Hallman GJ, Myers SW, Jessup AJ, Islam A 2011. Comparison of in vitro heat and cold tolerances of the new invasive species Bactrocera invadens (Diptera: Tephritidae) with three known tephritids. Journal of Economic Entomology 104: 21-25.

Heard TA, Heather NW, Peterson PM 1992. Relative tolerance to vapor heat-treatment of eggs and larvae of Bactrocera tryoni (Diptera, Tephritidae) in mangoes. Journal of Economic Entomology 85: 461-463.

Heimoana V, Tunupopo F, Toleafoa E, Fakanaiki C 1997. The fruit fly fauna of Tonga, Western Samoa, American Samoa and Niue. In: Allwood AJ, Drew RAI eds. Management of Fruit Flies in the Pacific. A regional symposium, Nadi, Fiji, 28-31 October 1996. Australian Centre for International Agricultural Research, Canberra. Pp. 57-59.

IPPC 2016. PT 21: Vapour heat treatment for Bactrocera melanotus and Bactrocera xanthodes on Carica papaya. International Plant Protection Convention. p. 1-2. https:// www.ippc.int/en/publications/82519/ (accessed 4 June 2019)

Li D, Waite DW, Gunawardana DN, McCarthy B, Anderson D, Flynn A, George S 2019. DNA barcoding and real-time PCR detection of Bactrocera xanthodes (Tephritidae: Diptera) complex. Bulletin of Entomological Research 109: 102-110.

McGregor A 1997. An economic evaluation of fruit fly research in the South Pacific. In: Allwood AJ, Drew RAI eds. Management of Fruit Flies in the Pacific. A regional symposium, Nadi, Fiji, 28-31 October 
1996. Australian Centre for International Agricultural Research, Canberra. Pp. 212221.

Molimau-Samasoni S, Vaaiva V, Seruvakula S, Tugaga A, Ortiz G, Wallace S, Seelye M, Waddell BC, Brown SDJ, Jamieson LE, Woolf A 2019. A comparison of postharvest quality of breadfruit (Artocarpus altilis) after disinfestation with hot air or hot water treatments. New Zealand Plant Protection 72: 67-74.

Neven LG 2000. Physiological responses of insects to heat. Postharvest Biology and Technology 21: 103-111.

Purea M, Putoa R, Munro E 1997. Fauna of fruit flies in the Cook Islands and French Polynesia. In: Allwood AJ, Drew RAI eds. Management of Fruit Flies in the Pacific. A regional symposium, Nadi, Fiji, 28-31 October 1996. Australian Centre for International Agricultural Research, Canberra. Pp. 54-56.

RCore Team 2015. R: Alanguage and environment for statistical computing. $\mathrm{R}$ Foundation for Statistical Computing, Vienna, Austria.

Sales F, Paulaud D, Maindonald J 1997. Comparison of egg and larval stage mortality of three fruit fly species (Diptera: Tephritidae) after immersion in hot water. In: Allwood AJ, Drew RAI eds. Management of Fruit Flies in the Pacific. A regional symposium, Nadi, Fiji, 28-31 October 1996. Australian Centre for International Agricultural Research, Canberra. Pp. 247-250.

San Jose M, Doorenweerd C, Leblanc L, Barr N, Geib SM, Rubinoff D 2018. Incongruence between molecules and morphology: a seven-gene phylogeny of Dacini fruit flies paves the way for reclassification (Diptera: Tephritidae). Molecular Phylogenetics and Evolution 121: 139-149.

Tora Vueti E, Ralulu L, Leweniqila L, Balawakula A, Frampton CM 1997. Heat tolerances of immature stages of Bactrocera passiflorae (Froggatt) and B. xanthodes (Broun) in Fiji. In: Allwood AJ, Drew RAI eds. Management of Fruit Flies in the Pacific. A regional symposium, Nadi, Fiji, 28-31 October
1996. Australian Centre for International Agricultural Research, Canberra. Pp. 234238.

Virgilio M, Jordaens K, Verwimp C, White IM, De Meyer M 2015. Higher phylogeny of frugivorous flies (Diptera, Tephritidae, Dacini): localised partition conflicts and a novel generic classification. Molecular Phylogenetics and Evolution 85: 171-179.

Waddell BC, Clare GK, Maindonald JH 1997a. Comparative mortality responses of two Cook Island fruit fly (Diptera: Tephritidae) species to hot water immersion. Journal of Economic Entomology 90: 1351-1356.

Waddell BC, Clare GK, Petry RJ, Maindonald JH, Purea M, Wigmore W, Joseph P, Fullerton RA, Batchelor TA, Lay-Yee M 1997b. Quarantine heat treatment for Bactrocera melanotus (Coquillett) and B. xanthodes (Broun) (Diptera: Tephritidae) in Waimanalo papaya in the Cook Islands. In: Allwood AJ, Drew RAI eds. Management of Fruit Flies in the Pacific. A regional symposium, Nadi, Fiji 28-31 October 1996. Australian Centre for International Agricultural Research, Canberra. Pp. 251-255.

Walker GP, Tora Vueti E, Hamacek EL, Allwood AJ 1997. Laboratory-rearing techniques for tephritid fruit flies in the South Pacific. In: Allwood AJ, Drew RAI eds. Management of Fruit Flies in the Pacific. A regional symposium, Nadi, Fiji, 28-31 October 1996. Australian Centre for International Agricultural Research, Canberra. Pp. 145152.

Xie Q, Hou B, Zhang R 2008. Thermal responses of oriental fruit fly (Diptera: Tephritidae) late third instars: mortality, puparial morphology, and adult emergence. Journal of Economic Entomology 101: 736-741.

Zar JH 1999. Biostatistical Analysis. Fourth Edition. Prentice Hall, USA. 929 p. 